\title{
Pharmacological Identification of Two Types of Presynaptic Voltage-Dependent Calcium Channels at CA3-CA1 Synapses of the Hippocampus
}

\author{
Ling-Gang Wu and Peter Saggau \\ Division of Neuroscience, Baylor College of Medicine, Houston, Texas 77030
}

The effects of voltage-dependent $\mathrm{Ca}$ channel (VDCC) antagonists on synaptic transmission were investigated at CA3CA1 synapses of guinea pig hippocampal slices. After selectively loading presynaptic structures in area CA1 with the calcium indicator fura-2, we simultaneously recorded a presynaptic calcium transient $\left([\mathrm{Ca}]_{t}\right)$ and the corresponding field excitatory postsynaptic potential (fEPSP) evoked by a single stimulus given to the Schaffer collateral-commissural (SCC) pathway. Application of nifedipine did not reduce either the [Ca], or the fEPSP, suggesting that nifedipine-sensitive $\mathrm{Ca}$ channels do not significantly contribute to evoked synaptic transmission at low stimulation frequency. Application of $\omega$-conotoxin GVIA ( $\omega$-CgTX) or $\omega$-agatoxin-IVA ( $\omega$-Aga-IVA) dose-dependently blocked both the $[\mathrm{Ca}]_{t}$ and the fEPSP. The time course of the block of the $[\mathrm{Ca}]_{t}$ was similar to that of the fEPSP. About $40 \%$ of the total $[\mathrm{Ca}]_{t}$ was $\omega$-CgTX sensitive, and more than $20 \%$ was $\omega$-Aga-IVA sensitive. Combined application of these two blockers showed no overlap of the $\omega$-CgTX-sensitive with the $\omega$-Aga-IVA-sensitive [Ca] These results suggest that there are at least two types of presynaptic VDCCs at CA3-CA1 synapses of the hippocampus: $\omega$-CgTX-sensitive and $\omega$-Aga-IVA-sensitive Ca channels. Our results also suggest that these two types of $\mathrm{Ca}$ channels are colocalized at a single presynaptic terminal.

During application of $\omega$-CgTX or $\omega$-Aga-IVA, the initial slope of the fEPSP varied approximately as the fourth power of the amplitude of the [Ca $]_{\text {, }}$ suggesting that $\omega$-CgTX-sensitive and $\omega$-Aga-IVA-sensitive $\mathrm{Ca}$ channels have about equal efficacy in triggering transmitter release. These results in combination with similar findings at the squid giant synapse suggest that the nonlinear relationship between transmitter release and the $\mathrm{Ca}$ influx is well conserved from the molluscan to the mammalian nervous system.

[Key words: hippocampus, presynaptic calcium, calcium

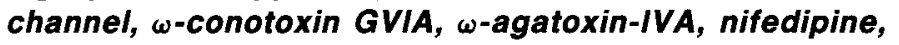
phenytoin, synaptic transmission, fura-2, guinea pig]

VDCCs play an important role in triggering transmitter release (Llinás, 1991; Zucker, 1993). Discrimination between these channel types has been based on several criteria, including gat-

\footnotetext{
Received Oct. 21, 1993; revised Feb. 16, 1994; accepted Mar. 24, 1994.

We thank Drs. R. Gray and D. Johnston for kindly allowing us to use some of their equipment. We also thank S. Sinha, B. Avery, and Drs. O. Delbono, R. Gray, and P. E. Schulz for critical and helpful comments on the manuscript. The computer software for data acquisition and analysis was developed by S. S. Patel.

Correspondence should be addressed to Dr. Peter Saggau at the above address. Copyright (C) 1994 Society for Neuroscience $0270-6474 / 94 / 145613-10 \$ 05.00 / 0$
}

ing, ionic conductance, and pharmacology. So far, at least four distinct types of VDCCs have been found: L-, N-, P-, and T-type channels (Fox et al., 1987a,b; Llinás et al., 1989). Many investigations have been carried out to classify the types of Ca channels in neuronal cell bodies of various species, and the recording of Ca currents at the soma of many types of neurons has become a routine practice (Tsien et al., 1988, 1991; Miller, 1992). However, except for few preparations such as the squid giant synapse (Llinás et al., 1976; Augustine et al., 1985a), the recording of Ca currents in presynaptic terminals, especially in the mammalian CNS, is very difficult and often impractical. 'To identify the types of VDCCs contributing to transmitter release in the mammalian CNS, pharmacological tools are often used.

Studies of the effects of specific $\mathrm{Ca}$ channel blockers on the postsynaptic potential in PNS and CNS have suggested that $\omega$-CgTX-sensitive $\mathrm{N}$-type $\mathrm{Ca}$ channels are involved in triggering transmitter release (Kerr and Yoshikami, 1984; Kamiya et al., 1988; Dutar et al., 1989; Horne and Kemp, 1991; Protti et al., 1991), but dihydropyridine-sensitive L-type Ca channels in most cases are not (Jones and Heinemann, 1987; Kamiya el al., 1988; Atchison, 1989; Hamilton and Smith, 1992). Recently, it has been found that funnel-web spider toxin (FTX), a P-type VDCC blocker (Llinás et al., 1989), inhibited synaptic transmission at squid giant synapse, neuromuscular junction, and parallel and climbing fiber synapses in cerebellum (Llinás et al., 1989; Uchitel et al., 1992; Sugimori et al., 1993); and $\omega$-Aga-IVA, another P-type VDCC blocker (Mintz et al., 1992b), reduced synaptic transmission at CA3-CA1 and mossy fiber-CA3 synapses of the hippocampus (Hirning et al., 1992; Ahlijanian ct al., 1993; Castillo et al., 1993; Luebke et al., 1993; Takahashi and Momiyama, 1993). These findings suggest that P-type Ca channels are present at presynaptic terminals.

The pharmacological effects of specific Ca channel blockers on high potassium-induced $\mathrm{Ca}$ uptake into synaptosomes, and high potassium-induced transmitter release from synaptosomes, brain slices, and PNS, have been extensively studied. Results from mammalian brain synaptosomes and brain slices have suggested in general that $\omega$-Aga-IVA-sensitive or FTX-sensitive P-type Ca channels constitute the majority of VDCCs involved in transmitter release (Llinás et al., 1989; Mintz et al., 1992b; Turner et al., 1992; Uchitel et al., 1992; Burke et al., 1993; Geer et al., 1993), that $\omega$-CgTX-sensitive N-type Ca channels constitute a smaller fraction (Reynolds et al., 1986; Dooley et al., 1987; Suszkiw et al., 1989; Lundy et al., 1990; Scheer, 1990; Pocock et al., 1992; Burke et al., 1993), and that L-typc Ca channels are largely not involved in transmitter release (Middlemiss and Spedding, 1985; Reynolds et al., 1986; Suszkiw et al., 1986; Scheer, 1990; Pocock et al., 1992; Geer et al., 1993). 
Optical methods with $\mathrm{Ca}$ indicators have been successfully used in monitoring the Ca transient in presynaptic terminals of a few preparations, including squid giant synapse (Charlton et al., 1982; Swandulla et al., 1991), crayfish neuromuscular junction (Delaney et al., 1989), and hippocampal mossy fiber synapses (Regehr and Tank, 1991). Recently, we have been able to use optical techniques to record simultaneously the presynaptic $[\mathrm{Ca}]_{t}$ and the fEPSP induced by a single electrical stimulation of the SCC pathway in hippocampal area CAl (Wu and Saggau, 1994). Here we describe an application of this technique to study directly the effects of several VDCC blockers, including nifedipine, $\omega$-CgTX, and $\omega$-Aga-IVA, on both the presynaptic [Ca] ${ }_{t}$ and the fEPSP in a population of hippocampal CA3-CAl synapses. We confirmed the earlier suggestion by demonstrating that $\omega$-CgTX and $\omega$-Aga-IVA block synaptic transmission by inhibiting the presynaptic [Ca] at CA3-CA1 synapses (Dutar et al., 1989; Horne and Kemp, 1991; Hirning et al., 1992). We also found that the $\omega-\mathrm{Cg} \Gamma X$-sensitive $[\mathrm{Ca}]_{t}$ constitutes about $40 \%$ of the total [Ca], evoked by single action potentials, and the $\omega$-Aga-IVA-scnsitive [Ca], constitutes more than $20 \%$.

In squid giant synapses the relationship between presynaptic Ca current and postsynaptic potential is nonlinear and follows a third-power function (Augustine et al., 1985b; Augustine and Charlton, 1986). This finding suggests the "cooperative" action of $\mathrm{Ca}$ in triggering transmitter release. By applying the nonspecific VDCC blocker cadmium, we obtained a similar result (Wu and Saggau, 1994). Transmitter release in area CA1 of hippocampus, as judged by the initial slope of the fEPSP, varied approximately with the fourth power of the presynaptic $\mathrm{Ca}$ influx, the volume average Ca current (Wu and Saggau, 1994). The presynaptic Ca channel in the squid giant synapse has been identified as P type using FTX (Llinás et al., 1989). It is important to know whether the relationship between transmitter release and the $\mathrm{Ca}$ influx through a particular type of VDCCs holds in the presynaptic terminals of the mammalian CNS. Our present results suggest that this power relationship is well conserved from the molluscan to the mammalian nervous system.

\section{Materials and Methods}

Brain slice preparation and electrical recording. Guinea pigs about 1-2 months old were anesthetized (methoxyflurane) and quickly decapitated. The brains were immediately removed and $400 \mu \mathrm{m}$ transverse hippocampal brain slices were prepared on a vibrating tissue cutter and stored in artificial cerebrospinal fluid containing (in mM) $\mathrm{NaCl}, 124$; $\mathrm{KCl}, 5 ; \mathrm{CaCl}_{2}, 2.5 ; \mathrm{MgCl}_{2}, 1.2 ; \mathrm{NaHCO}_{3}, 22 ;$ and D-glucose, 10 . The artificial cerebrospinal fluid was temperature controlled at $28-30^{\circ} \mathrm{C}$ and gassed with $95 \% \mathrm{O}_{2}$ and $5 \% \mathrm{CO}_{2}$, maintaining a constant $\mathrm{pH}$ of 7.4 . After a resting period of at least $1 \mathrm{hr}$, the slices were transferred to the recording chamber. Evoked fEPSPs (about $0.8-1.2 \mathrm{mV}$ in amplitude) were recorded from stratum radiatum with glass microelectrodes $(2 \mathrm{M}$ $\mathrm{NaCl}, 1-5 \mathrm{M} \Omega$ ). Before calculating the initial slopes of the fEPSPs, the signals were corrected for contamination by the presynaptic volleys by subtracting responses obtained during routine application of the glutamate antagonists 6-cyano-7-nitroquinoxaline-2,3-dione (CNQX; 10 $\mu \mathrm{M}$ ) and aminophosphonovalerate (APV; $50 \mu \mathrm{M}$; see Wu and Saggau, 1994). Data are expressed as mean \pm SEM.

Optical recording of the presynaptic Ca transient. The technique for selectively loading presynaptic structures including terminals of CA3$\mathrm{CAl}$ synapses with the $\mathrm{Ca}$ indicator fura- 2 has been described in detail elsewhere (Wu and Saggau, 1994). In brief, a small amount of fura-2 AM (Molecular Probes) solution (0.9 mM fura-2 AM, 10\% DMSO, and $1 \%$ pluronic acid) in a pipette with a tip diameter of about $2 \mu \mathrm{m}$ was pressure injected under visual control into stratum radiatum of area CA1 of the hippocampal slice (Fig. 1A). This resulted in loading and subsequent diffusion of the indicator via the SCC pathway to presynaptic terminals. About $1 \mathrm{hr}$ after injection, fluorescence emerging from an area with a diameter of about $150 \mu \mathrm{m}$ in stratum radiatum (Fig. $1 A$ shaded region), approximately $500 \mu \mathrm{m}$ from the injection site, was detected by a single photodiode, connected to a low-noise, current-tovoltage converter and amplifier. The optical recording system for the Ca signals includes an inverted microscope (Axiovert 10, Achroplan $50 \times, 0.9$ NA, Zeiss) equipped with a Xenon burner, an electromechanical shutter (Uniblitz, Vincent), and a quartz illuminator, as well as matched epifluorescence filter sets for ratio measurements (360:380 $\mathrm{nm}$; Omega). Calibration of $\mathrm{Ca}$ signals was obtained by forming the ratio between two continuous recordings $(100 \mathrm{msec})$ of fura- 2 fluorescence intensity at two excitation wavelengths with an interval of 2-5 $\sec$ (Grynkiewiez et al., 1985). The fluorescence intensities did not change significantly within this interval. The background fluorescence of the slice measured before the injection of fura-2 AM was subtracted. A viscosity correction was not made since its exact value is unknown. This factor could cause an error in our calculations of absolute $\mathrm{Ca}$ concentration, but should not interfere with the more important relative values. The amplitude of the [Ca], was measured as the difference between the maximal concentration and the resting level. Averaging techniques ( $n \leq 4$; interval, $10 \mathrm{sec}$ ) were used to improve the signal-to-noise ratio. Data in each experiment were normalized to baseline, then pooled together and expressed as mean \pm SEM. At the end of each experiment, the application of the glutamate antagonist (CNQX and APV) verified the presynaptic origin of the observed [Ca], by blocking the fEPSP but not the [Ca], (Fig. 1 in Wu and Saggau, 1994).

Drugs. Nifedipine (Sigma) was dissolved in DMSO and diluted in artificial cerebrospinal fluid. Since nifedipine is known to be photolabile (O'Regan et al., 1991), the drug solution was made up in the dark and used within $2 \mathrm{hr}$. Additional precautions were taken during optical recording (see Results). $\omega$-CgTX (fraction GVIA) was purchased from Sigma. $\omega$-Aga-IVA was obtained from Peptides International (Mintz and Bean, 1993).

\section{Results}

Nifedipine reduces neither the $[\mathrm{Ca}]_{\mathfrak{t}}$ nor the $f E P S P$

Following a selective loading of presynaptic structures of the CA3-CAl synapses with the $\mathrm{Ca}$ indicator fura-2 (Wu and Saggau, 1994), we simultaneously recorded the presynaptic [Ca] $]_{t}$ and the fEPSP evoked by single electrical stimulation of the SCC pathway in the stratum radiatum of area CAl of the hippocampal slice (Fig. $1 A$ ). Bath application of the L-type Ca channel blocker nifedipine $(10 \mu \mathrm{M})$ for $30 \mathrm{~min}$ did not affect either the $[\mathrm{Ca}]_{t}(101 \pm 2 \%)$ or the corresponding fEPSP $(104 \pm$ $4 \%, n=5)$. Figure $1, B$ and $C$, shows a typical experiment. Since nifedipine is light sensitive (O'Regan et al., 1991), we did not record the $\mathrm{Ca}$ transient during the first $20-30 \mathrm{~min}$ of application of this drug (Fig. 1B).

\section{$\omega-C g T X$ partially blocks both the [Ca], and the fEPSP}

Addition of $1 \mu \mathrm{M} \omega$-CgTX, an N-type Ca channel blocker (Olivera et al., 1985, 1990), partially suppressed both the $[\mathrm{Ca}]_{t}$ and the fEPSP (Fig. $2 A, B$ ). This suppression was not accompanied by a significant change of either the presynaptic resting $\mathrm{Ca}$ level (Fig. $2 A$ ) or the presynaptic volley (Fig. $2 B$ ), and was often irreversible. In some slices, the suppression partially recovered following a $30 \mathrm{~min}$ washout of $\omega$-CgTX (Fig. $2 \mathrm{~A}$ ). Figure $2 \mathrm{C}$ summarizes the dose-dependent suppression after $45 \mathrm{~min}$ of exposure to $\omega$-CgTX at different concentrations $(0.01-1 \mu \mathrm{M})$. The lowest concentration of $\omega$-CgTX we used (10 nM) weakly suppressed the $[\mathrm{Ca}]_{t}$ to $90 \pm 3 \%$ and the fEPSP to $63 \pm 8 \%$ of baseline $(n=4)$. The effects of $\omega$-CgTX were saturating at concentrations higher than $100 \mathrm{nM}$. At $\mathrm{l} \mu \mathrm{M}, \omega-\mathrm{Cg} \mathrm{CX}$ reduced the $[\mathrm{Ca}]_{t}$ to $59 \pm 8 \%$ and the corresponding fEPSP to $24 \pm 11 \%$ of baseline $(n=4)$. The time courses of suppression of the [Ca] and the fEPSP were similar (Fig. $2 A$ ), and were faster with higher concentrations of $\omega$ - $\mathrm{CgTX}$. The percentage reductions of the fEPSP by $\omega-\mathrm{CgTX}$ are similar to other reports at this synapse 
A

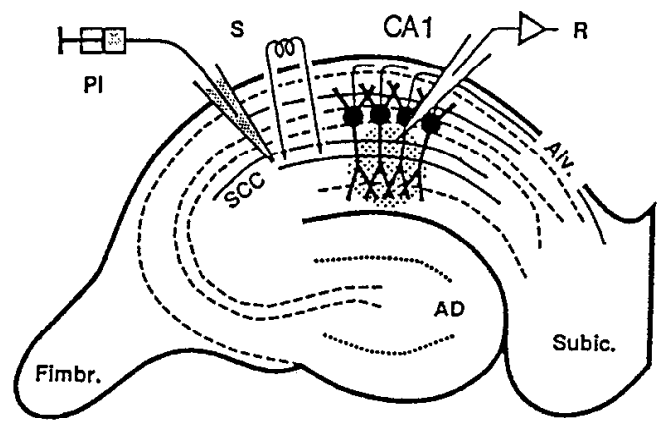

B

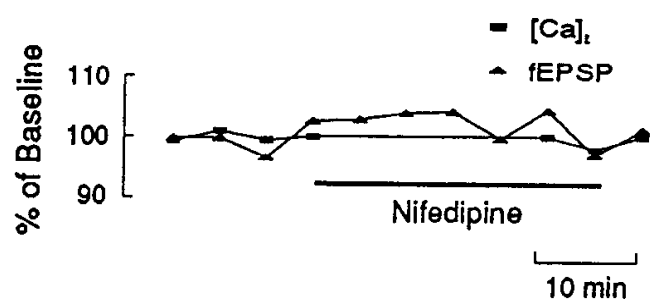

C
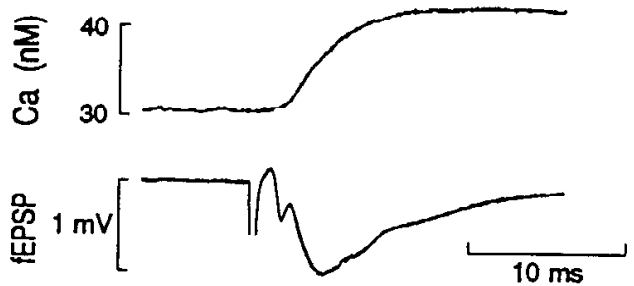

Figure 1. Nifedipine does not change either the [Ca $]_{t}$ or the fEPSP. $A$, Experimental arrangement. The membrane-permeant calcium indicator (fura-2 AM, $0.9 \mathrm{mM}$ ) was pressure injected $(P I)$ under visual control into stratum radiatum (SR). Fluorescence emerging from an area with a diameter of about $150 \mu \mathrm{m}$ in SR (shaded area), $500 \mu \mathrm{m}$ away from the injection site, was recorded by a single photodiode. The preparation was electrically stimulated by a bipolar electrode $(S)$ positioned in SR. An extracellular recording electrode $(R)$ was placed in about the center of the shaded region to record the fEPSP. $B$, No significant change of the [Ca] ${ }_{t}$ and the fEPSP during bath application of nifedipine $(10 \mu \mathrm{M})$. $C$, Sampled recordings of the $[\mathrm{Ca}]_{t}$ and the fEPSP before and during the application of nifedipine are superimposed.

(Dutar et al., 1989; Horne and Kemp, 1991) and at the mossy fiber-CA3 synapse (Kamiya et al., 1988).

The summarized data in Figure $2 C$ show that the relationship between the mean of the initial slope of the fEPSP $(Y)$ and the mean of the amplitude of the $[\mathrm{Ca}]_{t}(X)$ at each concentration was nonlinear. This relationship could be approximated by a power function,

$$
Y=X^{m},
$$

where $m=3.5$, and $X$ and $Y$ are normalized to their respective baselines. By substituting $X$ in Equation 1 with the measured mean [Ca], (normalized) at each concentration, different traces of the calculated fEPSP were obtaincd by varying the value of the exponent $m$. This exponent $m(m=3.5)$ was determined as the best fit of the calculated (Fig. $2 C, \square$ ) with the measured mean fEPSP (Fig. $2 C, \Delta$ ) as guessed by eye. The exponent ( $m$
A
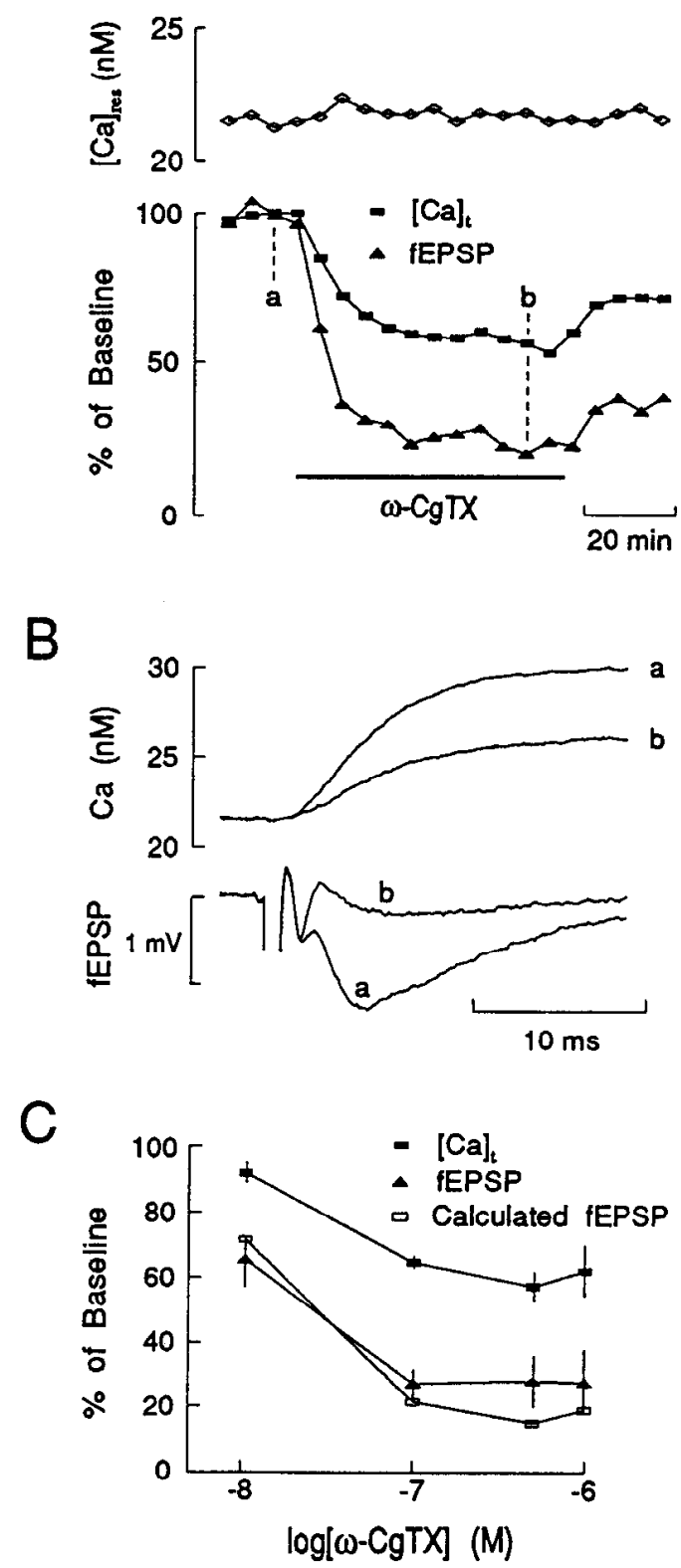

Figure 2. $\omega$-CgTX decreases both the $[\mathrm{Ca}]_{,}$and the fEPSP in area CA1 of hippocampus. $A$, A typical experiment showing the reduction of the $[\mathrm{Ca}]_{i}$ and the fEPSP during bath application of $1 \mu \mathrm{M} \omega$-CgTX (bottom graph). This reduction was not accompanied by a significant change of the resting $\mathrm{Ca}$ level $\left([\mathrm{Ca}]_{\text {res }}\right.$, top graph $)$. $B$, Sampled recordings of the $[\mathrm{Ca}]_{i}$ and the fEPSP taken at the times indicated in $A$. $C$, Dose response of $\omega$-CgTX block of the amplitude of the $[\mathrm{Ca}]_{t}(\mathbb{D})$ and the initial slope of the fEPSP ( $\triangle$ ). Observations (mean \pm SEM) from three or four slices for each concentration are normalized. The blocking effect was determined 45 min after application of $\omega$-CgTX. $\square$ represent the calculated slope of the fEPSP based on Equation 1, where $m=3.5$, and $X$ are taken from the measured $[\mathrm{Ca}]_{t}$ at each concentration.

$=3.5)$ in Equation 1 is similar to that $(m=3.6)$ obtained by applying the nonspecific VDCC blocker cadmium (Wu and Saggau, 1994), suggesting that reduction of the $[\mathrm{Ca}]_{t}$ is sufficient to account for the inhibition of synaptic transmission by $\omega-\mathrm{CgTX}$.

Augustine et al. (1985a) showed in the squid giant synapse that the integral over time of the presynaptic $\mathrm{Ca}$ current corresponds excellently to absorption signals obtained with arsen- 

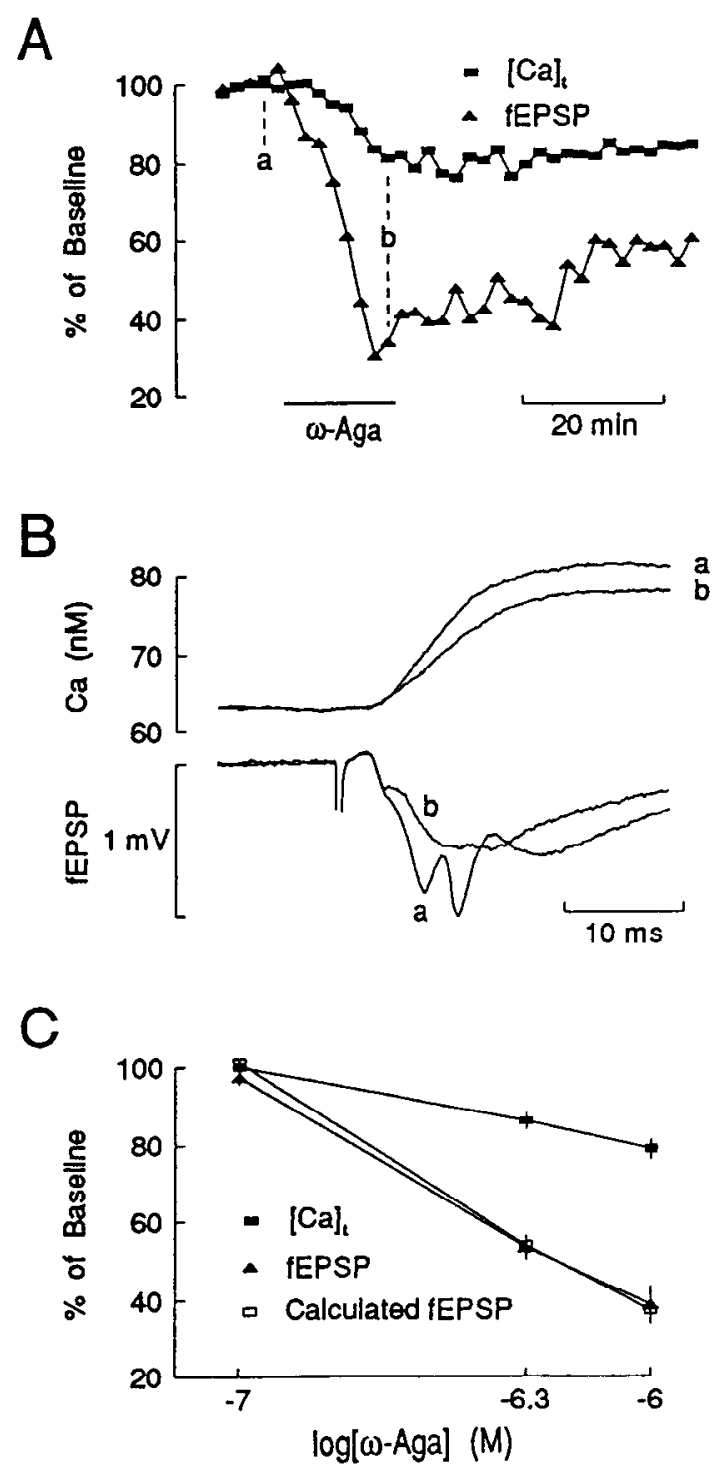

Figure 3. $\omega$-Aga-IVA decreases both the [Ca $]_{t}$ and the fEPSP. A, A typical cxpcriment showing the decrease of the $[\mathrm{Ca}]_{t}$ and the fEPSP during bath application of $\omega$-Aga-IVA $(\omega-A g a, 1 \mu \mathrm{M})$. $B$, Sampled recordings of the [Ca], and the fEPSP taken at the times indicated in $A$. $C$, Dose response of $\omega$-Aga-IVA block of the amplitude of the $[\mathrm{Ca}]_{t}(\square)$ and the initial slope of the fEPSP (A). Observations (mean \pm SEM) from three or four slices for each concentration are normalized. Block was determined 15 min after application of $\omega$-Aga-IVA. $\square$ represent the calculated slope of the fEPSP based on Equation 1, where $m=4.1$, and $X$ are taken from the measured [Ca], at each concentration.

azo III, another $\mathrm{Ca}$ indicator. Our Ca signals showed very little noise, which allowed us to take the reverse approach and differentiate the $\mathrm{Ca}$ transient to obtain a volume-averaged $\mathrm{Ca}$ influx, which is presumably proportional to the average presynaptic Ca current. As little is known about the endogenous $\mathrm{Ca}$ buffers in the presynaptic terminals, we made the assumption that the fura- 2 signal we recorded is proportional to the total amount of $\mathrm{Ca}$ that enters following an action potential. Thus, a curve proportional to the volume-averaged presynaptic $\mathrm{Ca}$ influx was obtaincd by taking the first derivative of the $\mathrm{Ca}$ transient over time (see Fig. 3 in Wu and Saggau, 1994). The time course of the volume-averaged $\mathrm{Ca}$ influx rather than that of the Ca transient was close to that of the fEPSP, suggesting that the volume-averaged $\mathrm{Ca}$ influx may reflect the time course of evoked transmitter release (Wu and Saggau, 1994). The amplitude of the volume-averaged $\mathrm{Ca}$ influx (normalized to baseline) was shown to be lincarly related to the amplitude of the [Ca $]_{t}$ (normalized) during application of cadmium at the same CA3-CA1 synapses (Wu and Saggau, 1994). This linear relationship was confirmed during application of $\omega$-CgTX (data not shown), suggesting that the amplitude of the $[\mathrm{Ca}]_{t}$ is proportional to the amplitude of the volume-averaged $\mathrm{Ca}$ influx or Ca current.

\section{$\omega$-Aga-IVA partially blocks both the [Ca], and the fEPSP}

Addition of $1 \mu \mathrm{M} \omega$-Aga-IVA partially reduced both the [Ca], and the fEPSP (Fig. $3 A, B$ ). The presynaptic volley (Fig. $3 B$; see also Fig. $4 B$ ) and the presynaptic resting $\mathrm{Ca}$ level (data not shown) did not change significantly during application of this drug. The reduction was irreversible or only slightly reversible after $45 \mathrm{~min}$ of washout (Fig. $3 \mathrm{~A}$ ). Figure $3 \mathrm{C}$ summarizes the dose-dependent reductions by $15 \mathrm{~min}$ exposure to $\omega$-Aga-IVA at different concentrations $(0.1-1 \mu \mathrm{M})$. At $100 \mathrm{nM}, \omega$-Aga-IVA had no significant effect on either the $[\mathrm{Ca}]_{t}(101 \pm 1 \%)$ or the fEPSP $(98 \pm 2 \%, n=3$ ). At $500 \mathrm{nM}, \omega$-Aga-IVA reduced the [Ca] to $86 \pm 2 \%$ and the fEPSP to $53 \pm 3 \%$ of baseline $(n=$ 3). At $1 \mu \mathrm{M}, \omega$-Aga-IVA reduced the [Ca] to $79 \pm 2 \%$ and the corresponding fEPSP to $39 \pm 5 \%$ of baseline $(n=4)$. Suppressions of the $[\mathrm{Ca}]_{\text {t }}$ and the fEPSP were of similar time courses (Fig. 3A), and were faster with higher concentrations of $\omega$-AgaIVA.

The summarized data in Figure $3 C$ show the nonlinear relationship between the mean of the initial slope of the fEPSP and the mean of the amplitude of the $[\mathrm{Ca}]_{t}$ at different concentrations. This relationship could also be approximated by Equation 1 with $m=4.1$. By substituting $X$ in Equation 1 with the measured mean [Ca], (normalized to baseline) at each tested concentration, the calculated fEPSP was obtained (Fig. $3 C, \square$ ), which closely resembled the measured fEPSP (Fig. $3 C, \Delta)$. The exponent $(m-4.1)$ in this equation is close to those obtained by applying either cadmium (Wu and Saggau, 1994) or $\omega-\mathrm{CgTX}$ (Fig. $2 C$ ), suggesting that $\omega$-Aga-IVA inhibits synaptic transmission by reducing the presynaptic [Ca]. The relationship between the amplitude of the [Ca], and the volume-averaged $\mathrm{Ca}$ influx (the first derivative over time of the $[\mathrm{Ca}]_{t}$ ) during application of $\omega$-Aga-IVA was linear (data not shown).

The concentration of $\omega$-Aga-IVA we used $(0.5-1 \mu \mathrm{M})$ to block the presynaptic $[\mathrm{Ca}]_{t}$ in the hippocampal slice is higher than that used (up to $200 \mathrm{~nm}$ ) to block P-type VDCCs in dissociated neurons and brain synaptosomes (Mintz et al., 1992a,b). The possibility that $\omega$-Aga-IVA may also block $\omega$-CgTX-sensitive

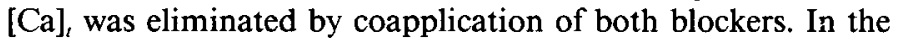
presence of $\omega$-CgTX, $\omega$-Aga-IVA still blocked both the $[\mathrm{Ca}]_{t}$ and the fEPSP; Figure $4, A$ and $B$, shows a typical experiment. Preexposing the hippocampal slices to $1 \mu \mathrm{M} \omega$-CgTX for $15-20 \mathrm{~min}$ reduced the $[\mathrm{Ca}]_{t}$ to $71 \pm 3 \%$ and the fEPSP to $38 \pm 4 \%$ of baseline $(n=3)$. Adding $1 \mu \mathrm{M} \omega$-Aga-IVA for $15 \mathrm{~min}$ further reduced the $[\mathrm{Ca}]$, to $47 \pm 6 \%$ and the fEPSP to $3 \pm 3 \%$ of the baseline $(n=3)$ (Fig. $4 C$ ). After 15-20 min exposure, $1 \mu \mathrm{M}$ $\omega$-CgTX usually achieved more than $80 \%$ of its maximal effect (as measured after $45 \mathrm{~min}$ exposure) and the remaining effect developed very slowly (Fig. $2 A$ ). Therefore, the measured additional inhibitory cffects of $\omega$-Aga-IVA in the presence of $\omega$-CgTX are mostly from $\omega$-Aga-IVA. The similar percentage decreases (relative to the controls before any drug application) of [Ca] ${ }_{t}$ caused by $\omega$-Aga-IVA in the presence $(25 \pm 3 \%, n=3)$ 
A

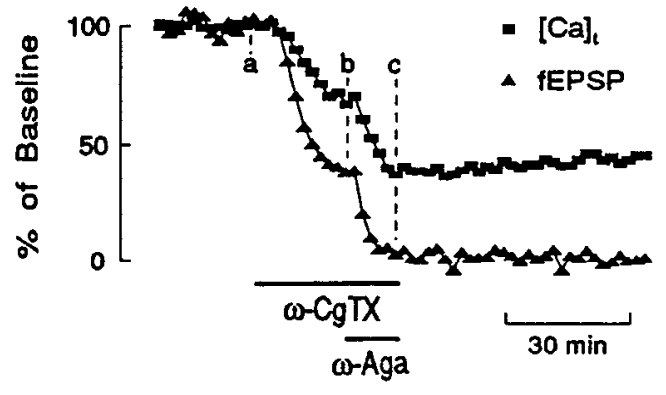

C

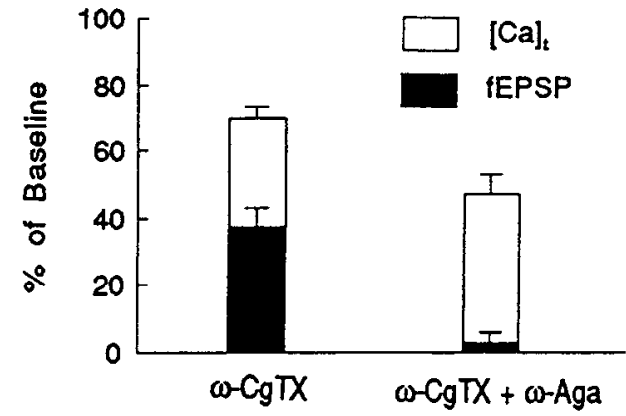

B

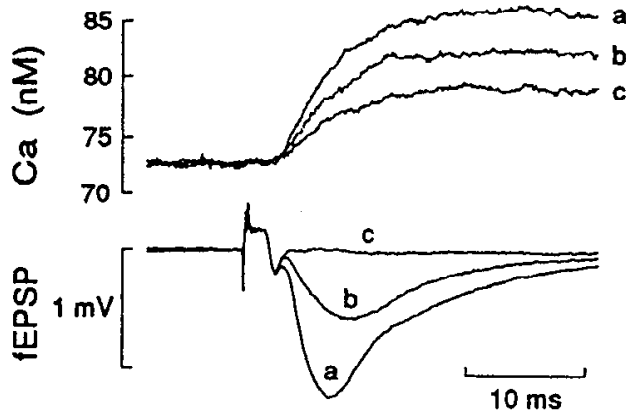

D

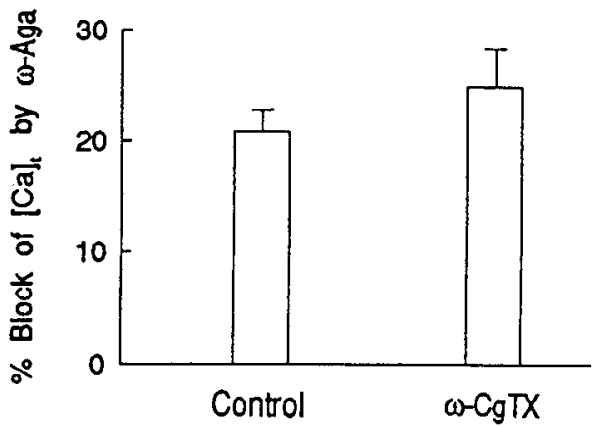

Figure 4. The blocking effect of $\omega$-Aga-IVA is not occluded by $\omega$-CgTX. $A$, A typical experiment showing the changes of the [Ca], and the fEPSP during application of $1 \mu \mathrm{M} \omega$-CgTX and $1 \mu \mathrm{M} \omega$-Aga-IVA $(\omega-A g a)$. B. Sampled recordings of the [Ca], and the fEPSP taken at the times indicated in $A$. $C$, Inhibition of both the [Ca], and the fEPSP during the application of $1 \mu \mathrm{M} \omega-\mathrm{CgTX}$ and coapplication of both $1 \mu \mathrm{M} \omega$-CgTx and $1 \mu \mathrm{M} \omega-\mathrm{Aga}-$ IVA. The block for $\omega$-CgTX was determined 15-20 min after its application. The block for combined application $(\omega-C g T X+\omega-A g a)$ was determined $15 \mathrm{~min}$ after the coapplication, which followed a preexposure to $\omega$-CgTX for 15-20 min. Observations (mean \pm SEM) from three slices were normalized to the baseline before application of $\omega$-CgTX. $D$, Comparison of the blocking effect of [Ca], by $\omega$-Aga-IVA in the absence (Control, $n$ $=4)$ and the presence of $\omega-\operatorname{CgTX}(n=3)$. Data were normalized to the baseline before application of both toxins.

and absence $(21 \pm 2 \%, n=4)$ of $\omega$-CgTX suggest that $\omega$-AgaIVA blocks a separate population of VDCCs without affecting $\omega$-CgTX-sensitive Ca channels (Fig. 4D).

\section{Discussion}

Using a combination of optical and electrophysiological techniques, we found two pharmacologically distinct presynaptic VDCCs, that is, $\omega$-CgTX-sensitive and $\omega$-Aga-IVA-sensitive Ca channels, which contribute to transmitter release evoked by single presynaptic action potentials at CA3-CA1 synapses in guinea pig hippocampal slices. We also compared the efficacy of these two types of presynaptic VDCCs in controlling transmitter release by determining the relationship between the fEPSP and the presynaptic $[\mathrm{Ca}]_{t}$ during application of either of the blockers.

\section{Fluorometric recording of the presynaptic Ca transient}

The technique to load selectively the presynaptic terminals with the $\mathrm{Ca}$ indicator fura-2, and the recording of the presynaptic $[\mathrm{Ca}]_{t}$ have been discussed in detail in a previous article $(\mathrm{Wu}$ and Saggau, 1994). Our data showed that cadmium (Wu and Saggau, 1994), $\omega$-CgTX, and $\omega$-Aga-IVA dose-dependently blocked both the presynaptic $[\mathrm{Ca}]_{t}$ and the fEPSP. During application of each of these blockers, the changes of the amplitude of the $[\mathrm{Ca}]_{t}$ and the initial slope of the fEPSP were of similar time courses, and the initial slope of the fEPSP varied approximately as the fourth power of the amplitude of the [Ca $]_{t}$. A dose-dependent block of the $[\mathrm{Ca}]_{t}$ and the fEPSP, similar time courses of the changes of the $[\mathrm{Ca}]_{t}$ and the fEPSP, and an approximately fourth power nonlinear relationship between the fEPSP and the $[\mathrm{Ca}]_{\text {, were }}$ also found during application of adenosine and the $\mathrm{GABA}_{\mathrm{B}}$ receptor agonist baclofen (Saggau et al., 1993; Wu and Saggau, 1993). Application of the potassium channel blocker 4-aminopyridine (L. G. Wu and P. Saggau, unpublished observations) or the adenosine $A_{1}$ antagonist 8-cyclopentyl-1,3-dipropylxanthine (Wu and Saggau, 1993) increased both the [Ca] and the fEPSP with a similar time course and a similar power relationship. So far, we have not found a manipulation that can modulate the presynaptic [Ca], without changing the fEPSP with a similar time course and with a roughly fourth power relationship. This evidence suggests that the recorded presynaptic $[\mathrm{Ca}]_{t}$ is an indicator of the local $\mathrm{Ca}$ that triggers transmitter release. Since the optical recording area may cover presynaptic terminals, where transmitter release occurs, as well as axons, our data imply that the $[\mathrm{Ca}]_{t}$ may be primarily from presynaptic terminals or from both terminals and the axons having VDCCs with similar pharmacological properties as terminals. In either case, we can study quantitatively the relative contribution of different types of presynaptic $\mathrm{Ca}$ channels to the [Ca], evoked by single action potentials. The presynaptic $\mathrm{Ca}$ accumulation evoked by tetanic stimulation at the crayfish neuromuscular junction has been shown to occur locally in boutons and small processes 
where synaptic vesicles and synaptic "active zones" are located (Zucker at al., 1991). This further supports the suggestion that the $[\mathrm{Ca}]_{t}$ is primarily from presynaptic terminals.

It is unlikcly that a detectablc fraction of the recorded presynaptic $[\mathrm{Ca}]_{t}$ is contributed by interneurons, because the number of inhibitory interneurons in a hippocampal slice is small and their processes are mostly not parallel to the SCC pathway (Brown and Zador, 1990). If a significant portion of the [Ca], is from interneurons, application of CNQX (10 $\mu \mathrm{M})$ and APV (50 $\mu \mathrm{M})$ should block the $\mathrm{Ca}$ signals from interneurons that are indirectly activated by CA3 axonal terminals; and antidromic stimulation of CAl pyramidal neurons should elicit a [Ca], due to indirect activation of interneurons. However, we failed to observe these phenomena (Fig. 1 in Wu and Saggau, 1994), suggesting that the interneurons indirectly activated by stimulation of CA3 axons were not loaded with fura-2. This makes it unlikely that a significant portion of the $\mathrm{Ca}$ signal is from interneurons directly activated by stimulation.

Sharp spatial $\mathrm{Ca}$ gradients have been demonstrated in presynaptic terminals during synaptic transmission (Swandulla et al., 1991; Llinás et al., 1992). The fura-2 signals in our experiments provide a measure of the averaged $\mathrm{Ca}$ concentration in the optical recording area covering terminals as well as axons, and as such may greatly underestimate the $\mathrm{Ca}$ concentration near the inner surface of the membrane where transmitter is released. This may result in a reduced amplitude of the [Ca] which was usually in the range of 10-20 nm in our experiments. Another factor contributing to the reduced amplitude of the $[\mathrm{Ca}]_{t}$ is that the measured $[\mathrm{Ca}]_{t}$ is the averaged $\mathrm{Ca}$ concentration for all the structures loaded with fura- 2 in the recording area, but not all of the loaded structures are stimulated. However, the amplitude of the [Ca], evoked by a stimulus with maximal intensity was less than $30-40 \mathrm{nM}$ (Wu and Saggau, unpublished observations), which is only about two to four times higher than that during routine experiments. Similar observations have recently been reported in single hippocampal mossy fiber terminals (Regehr et al., 1994) and the giant presynaptic terminals of the chick ciliary ganglion (Yawo and Chuhma, 1993); in both cases, a 10-30 nm increase of the Ca concentration was evoked by single nerve stimulus. Due to the above considerations, the amplitude change of the $[\mathrm{Ca}]$, during application of VDCC blockers in each experiment was expressed as the percentage of the [Ca] $]_{t}$ before the blocker application, and as such the absolute change of the $[\mathrm{Ca}]$, was normalized. The data were then pooled after such a normalization in each experiment.

Since the average $\mathrm{Ca}$ level may not be linearly related to the local $\mathrm{Ca}$ level, the power relationship we measured between the fEPSP and the [Ca] $]_{t}$ may not well reflect the relationship between the transmitter release and the local Ca level responsible for this release. Nevertheless, the measured power relationship is useful in comparing the relative efficacy of each type of presynaptic VDCCs in triggering transmitter release.

\section{Dihydropyridine-sensitive L-type Ca channels do not significantly participate in normal synaptic transmission}

The dihydropyridine antagonist nifedipine had no effect on either the presynaptic [Ca] $]_{t}$ or the fEPSP in area CAl of the hippocampus, suggesting that L-type Ca channels do not significantly participate in triggering transmitter release evoked by a single presynaptic action potential. Although the potency of dihydropyridines is voltage dependent (Docherty and Brown, 1986; Fox et al., 1987; Meyers and Barker, 1989; Ozawa et al.,
1989), at holding potentials around resting potential $(-60--80$ $\mathrm{mV}$ ) nifedipine (0.5-1 $\mu \mathrm{M})$ still blocked $30-60 \%$ of L-type $\mathrm{Ca}$ current in cultured hippocampal neurons (Meyers and Barker, 1989). Other dihydropyridine antagonists, such as nicardipine, nitrendipine, and nimodipine, were also shown to block a significant portion of the total high-threshold Ca current in hippocampal neurons activated from around resting potential (Ozawa et al., 1989; Mintz et al., 1992a). Assuming that at resting potential nifedipine can block $30-60 \%$ of the total L-type $\mathrm{Ca}$ current activated by an action potential, and having shown that a $5 \%$ decrease of the $[\mathrm{Ca}]_{t}$ is well detectable $(\mathrm{Wu}$ and Saggau, 1994), the lack of effect of nifedipine on the [Ca], suggests that L-type Ca channels contribute to less than $8-16 \%$ of the $[\mathrm{Ca}]_{t}$. Assuming further a fourth power relationship between the fEPSP and the $[\mathrm{Ca}]_{t}(\mathrm{Wu}$ and Saggau, 1994), and knowing a $10 \% \mathrm{de}-$ crease of the fEPSP is well detectable, then a $2.5 \%$ decrease of the $[\mathrm{Ca}]_{t}$ is indirectly detectable. Taken together, the lack of effect of nifedipine on the fEPSP would suggest that L-type Ca channels contribute to less than $4-8 \%$ of the $[\mathrm{Ca}]_{t}$. Our results are consistent with other reports that high potassium-induced Ca influx in brain synaptosomes (Reynolds et al., 1986; Suszkiw et al., 1986; Scheer, 1990; Pocock et al., 1992) and synaptic transmission in hippocampal slices (Jones and Heinemann, 1987; Kamiya et al., 1988) are usually insensitive to dihydropyridine antagonists. Both the L-type Ca channel blocker nifedipine and the activator BAY-K 8644 have also been shown to have no significant effect on presynaptic $\mathrm{Ca}$ influx induced by a train of stimulation $(5-20 \mathrm{~Hz}, 5-10 \mathrm{sec})$ as recorded with an extracellular ion-sensitive electrode in stratum radiatum of hippocampal area CA1 (Jones and Heinemann, 1987). This evidence corroborates our results very well. However, the possibility that presynaptic L-type Ca channels may be activated by other patterns of stimulation is not ruled out.

\section{$\omega$-CgTX-sensitive $N$-type Ca channels are present in presynaptic terminals}

We showed that $\omega-\mathrm{CgTX}$, but not nifedipine, inhibits synaptic transmission by reducing the presynaptic $\mathrm{Ca}$ influx without affecting the presynaptic volley at CA3-CAI synapses of the hippocampus. These results are consistent with other findings that $\omega$-CgTX inhibits synaptic transmission in area CA1 and CA3 of the hippocampus (Kamiya et al., 1988; Dutar et al., 1989; Horne and Kemp, 1991), suggesting that N-type Ca channels are present in presynaptic terminals of CA3-CAl synapses. As can be seen in the dose-response curve (Fig. $2 C$ ), about $40 \%$ of the $[\mathrm{Ca}]_{t}$ can be blocked by $\omega$-CgTX. In rat brain synaptosomes or tissue minces, it has been reported that high potassiuminduced $\mathrm{Ca}$ influx was either insensitive (Mintz et al., 1992b; Geer et al., 1993) or only partially sensitive to $\omega$-CgTX (Reynolds et al., 1986; Suszkiw et al., 1989; Lundy et al., 1990; Scheer, 1990; Pocock et al., 1992). The latter finding is in accordancc with our results. However, the heterogeneity of the brain synaptosomes or tissue minces and the long duration of the high potassium-induced depolarization (compared to the duration of a single action potential) make it difficult to compare our data to those from synaptosomes or tissue minces.

In several slices, the blocking effect of $\omega$-CgTX was slightly reversiblc. The reason is unclear. It has been reported that $\omega$-CgTX weakly and reversibly blocks T-type Ca channels in chick dorsal root ganglion neurons (McCleskey et al., 1987). Whether a small fraction of T-type Ca channels is blocked by 
$\omega$-CgTX in those slices showing slightly reversible effects of $\omega$-CgTX remains to be determined.

\section{$\omega-$ Aga-IVA-sensitive Ca channels are present in presynaptic terminals}

Our data showed that $\omega$-Aga-IVA inhibits synaptic transmission by reducing the presynaptic $\mathrm{Ca}$ transient without affecting the presynaptic volley in area CA1 of the hippocampus. The $\omega$-AgaIVA-sensitive fraction of the [Ca], did not overlap with the fraction blocked by $\omega$-CgTX, and no nifedipine-sensitive fraction of the $[\mathrm{Ca}]_{t}$ was found. These findings suggest that $\omega$-AgaIVA blocks a population of $\mathrm{Ca}$ channels other than $\mathrm{N}$ or $\mathrm{L}$ type in the investigated presynaptic terminals. This $\omega$-Aga-IVA-sensitive population of $\mathrm{Ca}$ channels in presynaptic terminals may have properties similar to the P-type Ca channels found in somata of many types of dissociated neurons (Mintz et al., 1992a,b; Mintz and Bean, 1993). Our results corroborate the recent evidence that $\omega$-Aga-IVA blocks synaptic transmission at CA3CA1 and mossy fiber-CA3 synapses (Hirning et al., 1992; Ahlijanian et al., 1993; Castillo et al., 1993; Luebke et al., 1993; Takahashi and Momiyama, 1993), reduces high potassium-induced $\mathrm{Ca}$ influx into brain synaptosomes and tissue minces (Mintz et al., 1992b; Geer et al., 1993), and inhibits glutamate release from rat brain synaptosomes and hippocampal slice in CA1 region (Turner et al., 1992; Burke et al., 1993).

The minimal effective concentration of $\omega$-Aga-IVA in our experiments was between 100 and $500 \mathrm{nM}$, which was higher than that used to block the P-type Ca current in somata of dissociated neurons (Mintz et al., 1992a,b; Mintz and Bean, 1993). One explanation may be that in our recording chamber the hippocampal slices were sitting on a glass coverslip, which may limit the fluid exchange at the bottom of the preparation, and the high molecular weight of $\omega$-Aga-IVA may hinder its diffusion into synaptic clefts in brain slices much more severely than onto somata of dissociated neurons. However, the glass coverslip in our recording chamber did not affect the blocking effect of $\omega$-CgTX, as the effect of $\omega$-CgTX on the fEPSP in our experiments is similar to those reported by other groups (Kamiya et al., 1988; Dutar et al., 1989; Horne and Kemp, 1991). Furthermore, the requirement for a high concentration (0.5-3 $\mu \mathrm{M})$ of $\omega$-Aga-IVA to block synaptic transmission in the hippocampal slice was also reported by several other groups (Hirning et al., 1992; Ahlijanian et al., 1993; Castillo et al., 1993), but a relatively low concentration (100-200 nM) of $\omega$-Aga-IVA was reported to inhibit the majority of the EPSP at CA3-CA1 synapses of the hippocampal slice (Luebke et al., 1993; Takahashi and Momiyama, 1993). The reason for this difference is unknown.

A recent report showed that high concentrations (200-800 nM) of $\omega$-Aga-IVA do not block T-, L-, or N-type Ca channels in sympathetic neurons (Mintz and Bean, 1993). Our results suggest that $1 \mu \mathrm{M} \omega$-Aga-IVA does not block $\mathrm{N}$-type Ca channels, and that L-type $\mathrm{Ca}$ channels are not activated by single stimulation in the investigated presynaptic terminals. Taken together, these results suggest that $\omega$-Aga-IVA at high concentrations does not block $\mathrm{T}-$, L-, or $\mathrm{N}$-type $\mathrm{Ca}$ channels at presynaptic terminals of hippocampal CA3-CA1 synapses. However, high concentrations of $\omega$-Aga-IVA have recently been found to partially block Q-type Ca channels, a new type of Ca channels defined as sensitive to $\omega$-conotoxin MVIIC but insensitive to nimodipine, $\omega-\mathrm{CgTX}$, and low concentrations of $\omega$-Aga-IVA (Randall et al., 1993; Sather et al., 1993). Q-type channels have also been proposed to be localized in the presynaptic terminals of rat hippocampal area CA1 (Randall et al., 1993). Therefore, it is possible that $\omega$-Aga-IVA at $1 \mu \mathrm{M}$ may also inhibit Q-type $\mathrm{Ca}$ channels. Currently, we do not know whether $\omega$-Aga-IVA reduces the presynaptic $[\mathrm{Ca}]_{t}$ by inhibiting $\mathrm{P}-$, Q-, or both types of $\mathrm{Ca}$ channels. Due to this consideration, we refer to the $\mathrm{Ca}$ channels blocked by $\omega$-Aga-IVA as $\omega$-Aga-IVA-sensitive type. Further classification of $\omega$-Aga-IVA-sensitive channels requires examination of the occlusion between the blocking effects of $\omega$-Aga-IVA and $\omega$-conotoxin MVIIC on the [Ca].

\section{Presynaptic Ca channels resistent to nifedipine, $\omega-C g T X$, and $\omega$-Aga-IVA}

In the presence of high concentrations of both $\omega-\mathrm{CgTX}$ and $\omega$-Aga-IVA, more than $40 \%$ of the [Ca], still remained (Fig. 4), and this component was not sensitive to nifedipine (Fig. 1). Although there may in principle exist $\mathrm{N}$ - and $\mathrm{P}$-type $\mathrm{Ca}$ channels insensitive to $\omega$-CgTX (Plummer et al., 1989) and $\omega$-Aga-IVA, it seems unlikely that unblocked $\mathrm{N}$ - and P-type Ca channels could account for more than $40 \%$ of the [Ca $]_{t}$ remaining in the presence of these two blockers. It is also highly unlikely that the reversal of $\mathrm{Na} / \mathrm{Ca}$ exchange could explain the remaining $[\mathrm{Ca}]_{t}$ (Zucker, 1993), because high concentrations of the nonspecific VDCC blocker cadmium (1-5 mM) completely blocked the [Ca], (Wu and Saggau, unpublished observations), and the short rise time of the $[\mathrm{Ca}]_{t}$ did not change significantly after application of any blocker we used (Figs. 2-4). It is more likely that other types of Ca channels resistant to $\mathrm{N}_{-}, \mathrm{P}_{-}$, and L-type $\mathrm{Ca}$ channel blockers, such as $\mathrm{T}$ type and/or some unidentified type, are present in presynaptic terminals. Interestingly, a component of Ca current that remains unblocked in the combined presence of N-, P-, and L-type Ca channel blockers has been found in the soma of several types of neurons, including CA3 pyramidal neurons of the hippocampus (Mintz et al., 1992a; Dolphin et al., 1993). Recently, we found that adenosine and the $\mathrm{GABA}_{\mathrm{B}}$ agonist baclofen inhibit the fEPSP primarily by reducing the $[\mathrm{Ca}]_{,}$at the same synapses, and the reduced [Ca], is partially due to inhibition of $\omega$-CgTx-sensitive, $\omega$-Aga-IVA-insensitive Ca channels (Saggau et al., 1993; Wu and Saggau, 1993 and unpublished observations). Following a preapplication of $1 \mu \mathrm{M}$ $\omega$-CgTX, both adenosine and baclofen further reduced the $[\mathrm{Ca}]_{t}$ and the fEPSP, suggesting that adenosine and baclofen also inhibit the fEPSP by reducing the $\omega$-CgTX-resistent and $\omega$-AgaIVA-resistent [Ca]. Taken together, our data suggest that some presynaptic $\mathrm{Ca}$ channcls resistent to $\mathrm{P}-, \mathrm{N}$-, and L-type $\mathrm{Ca}$ channel blockers may also be involved in triggering transmitter release at CA3-CA1 synapses.

Recently, based on the evidence that $\omega$-conotoxin MVIIC potently blocks synaptic transmission, Q-type Ca channels have been proposed to be localized in presynaptic terminals of CA3CA1 synapses of rat hippocampus (Wheeler et al., 1993). It is possible that the presynaptic [Ca] insensitive to nifedipine, $\omega$-CgTX, and $\omega$-Aga-IVA is partly or completely due to Q-type $\mathrm{Ca}$ channels. Further classification of Q-type Ca channels may require examination of the blocking effect of $\omega$-conotoxin MVIIC on the presynaptic $[\mathrm{Ca}]_{t}$ in the presence of $\omega-\mathrm{CgTX}$ and $\omega$-AgaIVA.

$\omega-C g T X$-sensitive and $\omega$-Aga-IVA-sensitive Ca channels trigger transmitter release with about the same efficacy

The initial slope of the fEPSP was found to be approximatcly proportional to the fourth power of the amplitude of the [Ca], 
during bath application of $\omega$-CgTX ( $m=3.5$; see Eq. 1), $\omega$-AgaIVA $(m=4.1)$, or cadmium ( $m=3.6)$ (Wu and Saggau, 1994). Since the amplitude of the $[\mathrm{Ca}]_{\ell}$ is proportional to the volumeaveraged Ca influx or Ca current (Wu and Saggau, 1994), the fEPSP is also approximately the fourth power of the volumeaveraged $\mathrm{N}$-type or $\omega$-Aga-IVA-sensitive $\mathrm{Ca}$ influx or $\mathrm{Ca}$ current. This result is similar to the finding that the postsynaptic potential is about the third power of the presynaptic Ca current in the squid giant synapse (Augustine, 1985b, 1986). The presynaptic $\mathrm{Ca}$ current in the squid giant synapse has been identified as P-type Ca current using FTX (Llinás et al., 1989). Taken together, these data suggest that the nonlinear relationship between transmitter release and the $\mathrm{Ca}$ influx through $\mathrm{N}$-or $\mathrm{P}$-type $\mathrm{Ca}$ channel is well conserved from molluscan to the mammalian nervous system. Our results indicate that $\omega$-CgTX-sensitive $\mathrm{Ca}$ channels, $\omega$-Aga-IVA-sensitive Ca channels, or the sum of all types of VDCCs in the presynaptic terminals trigger transmitter release with about the same efficacy in the CA3-CA1 synapses.

The nonlinear relationship between transmitter release and the presynaptic $\mathrm{Ca}$ influx provides an efficient control of transmitter release by modifying presynaptic VDCCs. Many transmitters and modulators, such as glutamate, GABA, and adenosine, have been reported to modulate the VDCCs in the soma of neurons (e.g., Scholz and Miller, 1991; Swartz and Bean, 1992; see also Nicoll et al., 1990, for review) and to inhibit transmitter release at many synapses (e.g., Dutar and Nicoll, 1988; Baskys and Malenka, 1991; Scholz and Miller, 1991; Barrie and Nicholls, 1993). It would be quite efficient if these transmitters or modulators inhibit transmitter release by modulating the presynaptic $\mathrm{Ca}$ influx. Adenosine and baclofen have been shown to inhibit synaptic transmission primarily by reducing the presynaptic $[\mathrm{Ca}]_{t}$ in area $\mathrm{CA}$ l of the hippocampus (Saggau et al., 1993; Wu and Saggau, 1993), although it has also been suggested that these two substances inhibit spontaneous transmitter release by mechanisms independent of inhibition of presynaptic Ca influx (Scanziani et al., 1992; Scholz and Miller, 1992).

\section{Colocalization of $\omega-C g T X-$ and $\omega-A g a-I V A-$ sensitive $C a$ channels at single presynaptic terminals}

Our data show that $\omega$-CgTX-sensitive and $\omega$-Aga-IVA-sensitive Ca channels coexist in the same population of presynaptic terminals. Since the $\mathrm{Ca}$ signals we recorded are an average from a number of presynaptic terminals (Wu and Saggau, 1994), we do not have direct evidence that a single presynaptic terminal contains both $\omega$-CgTX-and $\omega$-Aga-IVA-sensitive Ca channels. Assuming that these two types of $\mathrm{Ca}$ channels are segregated into different terminals, then the fEPSP is contributed by at least these two types of synapses containing presynaptic $\omega-\mathrm{CgTX}$ - or $\omega$-Aga-IVA-sensitive Ca channels alternatively. The sum of the fEPSP contributed by these two types of synapses must not exceed $100 \%$. As shown in Figure 2, a saturating concentration $(1 \mu \mathrm{M})$ of $\omega$-CgTX inhibited the fEPSP by $76 \pm 11 \%(n=4)$. Under the above assumption, this would indicate that $76 \pm$ $11 \%$ of the fEPSP was contributed by synapses containing presynaptic $\omega$-CgTX-sensitive Ca channels. Similarly, $\omega$-Aga-IVA at $1 \mu \mathrm{M}$ inhibited the fEPSP by $61 \pm 5 \%(n=4)$, indicating that $61 \pm 5 \%$ of the fEPSP was contributed by synapses containing presynaptic $\omega$-Aga-IVA-sensitive Ca channels. The sum of the fEPSP contributed by these two types of synapses is $137 \pm 7 \%$. The $95 \%$ confidence interval for the mean of the sum of the fEPSP is $137 \pm 17 \%$, which is much more than $100 \%$. Therefore, the above assumption is not accepted. It is highly unlikely that $\omega$-CgTX-and $\omega$-Aga-IVA-sensitive Ca channels are completely segregated into different presynaptic terminals.

The above analysis suggests that $\omega$-CgTX- and $\omega$-Aga-IVAsensitive $\mathrm{Ca}$ channels are colocalized at the same presynaptic terminal. The colocalization of two types of $\mathrm{Ca}$ channels in the same presynaptic terminal is of biological significance for several reasons: (1) in case one type of $\mathrm{Ca}$ channel is not functioning, the other type of $\mathrm{Ca}$ channel may prevent complete block of synaptic transmission; (2) different types of $\mathrm{Ca}$ channels may be differentially modulated by patterns of stimulation or by endogenous substances (e.g., Mogul et al., 1993; Yawo and Chuhma, 1993; for review, see Nicoll et al., 1990), thus providing a variety of mechanisms for presynaptic modulation of transmitter release.

\section{References}

Ahlijanian MK, Andrews G, Guarino B, Saccomano NA, Hirning LD, Mueller AL, Alasti N, Siok CJ, Welch MJ, Ganong AH, Volkmann RA (1993) Production and biological characterization of synthetic $\omega$-AgaIVA. Soc Neurosci Abstr 19:1753.

Atchison WD (1989) Dihydropyridine-sensitive and -insensitive components of acetylcholine release from rat motor ncrve tcrminals. $J$ Pharmacol Exp Ther 251:672-678.

Augustine GJ, Charlton MP (1986) Calcium dependence of presynaptic calcium current and post-synaptic response at the squid giant synapse. J Physiol (Lond) 381:619-640.

Augustine GJ, Charlton MP, Smith SJ (1985a) Calcium entry into voltage-clamped presynaptic terminals of squid. J Physiol (Lond) 367 : 143-162.

Augustine GJ, Charlton MP, Smith SJ (1985b) Calcium entry and transmitter release at voltage-clamped nerve terminals of squid. $\mathrm{J}$ Physiol (Lond) 369:163-181.

Barrie AP, Nicholls DG (1993) Adenosine Al receptor inhibition of glutamate exocytosis and protein kinase $\mathrm{C}$-mediated decoupling. J Neurochem 60:1081-1086.

Baskys A, Malenka RC (1991) Agonists at metabotropic glutamate receptors presynaptically inhibit EPSCs in neonatal rat hippocampus. J Physiol (Lond) 444:687-701.

Brown TH, Zador AM (1990) Hippocampus. In: The synaptic organization of the brain (Shepherd GM, ed), pp 346-388. New York: Oxford UP.

Burke SP, Adams ME, Taylor CP (1993) Inhibition of endogenous glutamate release from hippocampal tissue by $\mathrm{Ca}^{2+}$ channel toxins. Eur J Pharmacol 238:383-386.

Castillo PE, Weisskopf MG, Nicoll RA (1993) The role of $\mathrm{N}$ - and P-type calcium channels in mossy fiber (MF) synaptic transmission in the hippocampus. Soc Neurosci Abstr 19:903.

Charlton MP, Smith SJ, Zucker RS (1982) Role of presynaptic calcium ions and channels in synaptic facilitation and depression at the squid giant synapse. J Physiol (Lond) 323:173-193.

Delaney KR, Zucker RS, Tank DW (1989) Calcium in motor nerve terminals associated with posttetanic potentiation. J Neurosci 9:35583567.

Docherty RJ, Brown DA (1986) Interaction of 1,4-dihydropyridines with somatic Ca currents in hippocampal CA1 neurones of the guinea pig in vitro. Neurosci Lett 70:110-115.

Dolphin AC, Pearson HA, Menon-Johansson AS, Sweeney MI, Sutton K, Huston E, Cullen GP, Scott RH (1993) G protein modulation of voltage-dependent calcium channels and transmitter release. Biochem Soc Trans 21:391-395.

Dooley DJ, Lupp A, Hertting G (1987) Inhibition of central neurotransmitter release by $\omega$-conotoxin GVIA, a peptide modulator of the $\mathrm{N}$-type voltage-sensitive calcium channel. Naunyn Schmiedebergs Arch Pharmacol 336:467-470.

Dutar P, Nicoll RA (1988) Pre- and postsynaptic GABA $_{b}$ receptors in the hippocampus have different pharmacological properties. Neuron 1:585-591.

Dutar P, Rascol O, Lamour Y (1989) $\omega$-Conotoxin GVIA blocks synaptic transmission in the CA1 field of the hippocampus. Eur J Pharmacol 174:261-266.

Fox AP, Nowicky MC, Tsien RW (1987a) Kinetic and pharmacolog- 
ical properties distinguishing three types of calcium currents in chick sensory neurones. J Physiol (Lond) 394:149-172.

Fox AP, Nowicky MC, Tsien RW (1987b) Single-channel recordings of three types of calcium channels in chick sensory neurones. J Physiol (Lond) 394:173-200.

Geer JJ, Dooley DJ, Adams ME (1993) $\mathrm{K}^{+}$-stimulated ${ }^{45} \mathrm{Ca}^{2+}$ flux into rat neocortical mini-slices is blocked by $\omega$-Aga-IVA and the dual $\mathrm{Na}^{+} / \mathrm{Ca}^{2+}$ channel blockers lidoflazine and flunarizine. Neurosci Lett 158:97-100.

Griffith WH, Taylor L (1988) Phenytoin reduces excitatory synaptic transmission and post-tetanic potentiation in the in vitro hippocampus. J Pharmacol Exp Ther 246:851-858.

Grynkiewiez G, Poenie M, Tsien RY (1985) A new generation of Ca+ ${ }^{++}$ indicators with greatly improved fluorescence properties. J Biol Chem 260:3440-3450.

Hamilton BR, Smith DO (1992) Calcium currents in rat motor nerve terminals. Brain Res 584:123-131.

Hirning LD, Artman LD, Alasti N, Phillips D, Volkmann RA, Saccomano NA, Mueller AL (1992) Biological characterization of the novel calcium channel blocker $\omega$-Aga-IVA in mammalian CNS. Soc Neurosci Abstr 18:970.

Horne AL, Kemp JA (1991) The effect of $\omega$-conotoxin GVIA on synaptic transmission within the nucleus accumbens and hippocampus of the rat in vitro. Br J Pharmacol 103:1733-1739.

Jones RSG, Heinemann UH (1987) Differential effects of calcium entry blockers on pre- and postsynaptic influx of calcium in the rat hippocampus in vitro. Brain Res 416:257-266.

Kamiya H, Sawada S, Yamamoto C (1988) Synthetic $\omega$-conotoxin blocks synaptic transmission in the hippocampus in vitro. Neurosci Lett 91:84-88.

Llinás RR (1991) Depolarization release coupling: an overview. Ann NY Acad Sci 635:3-17.

Llinás RR, Steinberg IZ, Walton K (1976) Presynaptic calcium currents and their relation to synaptic transmission: voltage clamp study in squid giant synapse and theoretical model for the calcium gate. Proc Natl Acad Sci USA 73:2918-2922.

Llinás RR, Sugimori M, Lin JW, Cherksey B (1989) Blocking and isolation of a calcium channel from neurons in mammals and cephalopods utilizing a toxin fraction (FTX) from funnel-web spider poison. Proc Natl Acad Sci USA 86:1689-1693.

Llinás R, Sugimori M, Silver RB (1992) Microdomains of high calcium concentration in a presynaptic terminal. Science 256:677-679.

Luebke JL, Dunlap K, Turner TJ (1993) Multiple calcium channel types control glutamatergic synaptic transmission in the hippocampus. Neuron 11:895-902.

Lundy PM, Frew R, Fuller TW, Hamilton MG (1989) Pharmacological evidence for an $\omega$-conotoxin, dihydropyridine-insensitive neuronal $\mathrm{Ca}^{2+}$ channel. Eur J Pharmacol 206:61-68.

McCleskey EW, Fox AP, Feldman DH, Cruz LJ, Olivera BM, Tsien RW (1987) $\omega$-Conotoxin: direct and persistent blockade of specific types of calcium channels in neurons but not muscle. Proc Natl Acad Sci USA 84:4327-4331.

Meyers DE, Barker J (1989) Whole-cell patch-clamp analysis of voltage-dependent calcium conductances in cultured embryonic rat hippocampal neurons. J Neurophysiol 61:467-477.

Middlemiss DN, Spedding M (1985) A functional correlate for the dihydropyridine binding site in rat brain. Nature 314:94-96.

Miller RJ (1992) Voltage-sensitive $\mathrm{Ca}^{2+}$ channels. J Biol Chem 267: $1403-1406$

Mintz IM, Bean BP (1993) Voltage-dependence of P-type calcium channel block by synthetic $\omega$-Aga-IVA. Soc Neurosci Abstr 19:1478.

Mintz IM, Adams ME, Bean BP (1992a) P-type calcium channels in rat central and peripheral neurons. Neuron 9:85-95.

Mintz IM, Venema VJ, Swiderek KM, Lee TD, Bean BP, Adams ME (1992b) P-type calcium channels blocked by the spider toxin $\omega$-AgaIVA. Nature 355:827-829.

Mogul DJ, Adams ME, Fox AP (1993) Differential activation of adenosine receptors decreases $\mathrm{N}$-type but potentiates $\mathrm{P}$-type $\mathrm{Ca}^{2+}$ current in hippocampal CA3 neurons. Neuron 10:327-334.

Nicoll RA, Malenka RC, Kauer JA (1990) Functional comparison of neurotransmitter receptor subtypes in mammalian central nervous system. Physiol Rev 70:513-565.

Olivera BM, Gray WR, Zeikus R, Mcintosh JM, Varga J, River J, Santos V, Cruz LJ (1985) Peptide neurotoxins from fish-hunting cone snails. Science 230:1338-1343.

Olivera BM, Rivier J, Clark C, Ramilo CA, Corpuz GP, Abogadie Fe
C, Mena EE, Woodward SR, Hillyard DR, Cruz LJ (1990) Diversity of conus neuropeptides. Science 249:257-263.

O'Regan MH, Kocsis JD, Waxman SG (1991) Nimodipine and nifedipine enhance transmission at the Schaffer collateral CA1 pyramidal neuron synapse. Exp Brain Res 84:224-228.

Ozawa S, Tsuzuki K, Iino M, Ogura A, Kudo Y (1989) Three types of voltage-dependent calcium current in cultured rat hippocampal neurons. Brain Res 495:329-336.

Plummer MR, Logothetis DE, Hess P (1989) Elementary properties and pharmacological sensitivities of calcium channels in mammalian peripheral neurons. Neuron 2:1453-1463

Pocock JM, Venema VJ, Adams ME (1992) $\omega$-Agatoxins differentially block calcium channels in locust, chick and rat synaptosomes. Neurochem Int 20:263-270.

Protti DA, Szczupak L, Scornik FS, Uchitel OD (1991) Effect of $\omega$-conotoxin GVIA on neurotransmitter release at the mouse neuromuscular junction. Brain Res 557:336-339.

Randall AD, Wendland B, Schweizer F, Miljanich G, Adams ME, Tsien RW (1993) Five pharmacologically distinct high voltage-activated $\mathrm{Ca}^{2+}$ channels in cerebellar granule cells. Soc Neurosci Abstr 19:1478.

Regehr WG, Tank DW (1991) Selective fura-2 loading of presynaptic terminals and nerve cell processes by local perfusion in mammalian brain slice. J Neurosci Methods 37:111-119.

Regehr WG, Delaney KR, Tank DW (1994) The role of presynaptic calcium in short-term enhancement at the hippocampal mossy fiber synapse. J Neurosci 14:523-537.

Reynolds IJ, Wagner JA, Snyder SH, Thayer SA, Olivera BM, Miller RJ (1986) Brain voltage-sensitive calcium channel subtypes differentiated by $\omega$-conotoxin fraction GVIA. Proc Natl Acad Sci USA 83: 8804-8807.

Saggau P, Wu LG, Thalmann RH (1993) Baclofen inhibits synaptic transmission primarily by reducing the presynaptic calcium influx at CA3-CA1 synapses of guinea pig hippocampus. Soc Neurosci Abstr 19:1519.

Sather WA, Tanabe T, Zhang JF, Mori Y, Adams ME, Tsien RW (1993) Distinctive biophysical and pharmacological properties of class A (BI) calcium channel $\alpha_{1}$ subunits. Neuron 11:291-303.

Scanziani M, Capogna M, Gahwiler BH, Thompson SM (1992) Presynaptic inhibition of miniature excitatory synaptic currents by baclofen and adenosine in the hippocampus. Neuron 9:919-927.

Schecr HW (1990) Interactions between the presynaptically active neurotoxins $\alpha$-latrotoxin and $\omega$-conotoxin GVIA: studies on calcium fluxes and binding parameters in rat and chicken synaptosomes. Can J Physiol Pharmacol 68:1049-1054.

Scholz KP, Miller RJ (1991) GABA-b receptor-mediated inhibition of Ca currents and synaptic transmission in cultured rat hippocampal neurones. J Physiol (Lond) 444:669-686.

Scholz KP, Miller RJ (1992) Inhibition of quantal transmitter release in the absence of calcium influx by a $G$ protein-linked adenosine receptor at hippocampal synapses. Neuron 8:1139-1150.

Sugimori M, Cherksey B, Llinás R (1993) P-type calcium channels are responsive for transmission at the parallel and climbing fiber synapses in purkinje cells. Soc Neurosci Abstr 19:1526.

Suszkiw JB, O'Leary ME, Murawsky MM, Wang T (1986) Presynaptic calcium channels in rat cortical synaptosomes: fast-kinetics of phasic calcium influx, channel inactivation, and relationship to nitrendipine receptors. J Neurosci 6:1349-1357.

Suszkiw JB, Murawsky MM, Shi M (1989) Further characterization of phasic calcium influx in rat cerebrocortical synaptosomes: inferences regarding calcium channel type(s) in nerve endings. J Neurochem 52:1260-1269.

Swandulla D, Hans M, Zipser K, Augustine GJ (1991) Role of residual calcium in synaptic depression and posttetanic potentiation: fast and slow calcium signaling in nerve terminals. Neuron 7:915-926.

Swartz KJ, Bean BP (1992) Inhibition of calcium channels in rat CA3 pyramidal neurons by a metabotropic glutamate receptor. J Neurosci $12: 4358-4371$

Takahashi T, Momiyama A (1993) Different types of calcium channels mediate central synaptic transmission. Nature 366:156-158.

Tsien RW, Lipscombe D, Madison DV, Bley KR, Fox AP (1988) Multiple types of neuronal calcium channels and their selective modulation. Trends Neurosci 11:431-438.

Tsien RW, Ellinor PT, Horne WA (1991) Molecular diversity of voltage-dependent $\mathrm{Ca}^{2+}$ channels. Trends Pharmacol Sci 12:349-354.

Turner TJ, Adams ME, Dunlap K (1992) Calcium channels coupled to glutamate release identified by $\omega$-Aga-IVA. Science 258:310-313. 
Uchitel OD, Protti DA, Sanchez V, Cherksey BD, Sugimori M, Llinás RR (1992) P-type voltage-dependent calcium channel mediates presynaptic calcium influx and transmitter release in mammalian synapses. Proc Natl Acad Sci USA 89:3330-3333.

Wheeler DB, Tsien RW, Randall AD (1993) A calcium channel with novel pharmacology supports synaptic transmission and plasticity in the hippocampus. Soc Neurosci Abstr 19:909.

Wu LG, Saggau P (1993) Adenosine inhibits synaptic transmission by reducing the presynaptic calcium influx at CA3-CA1 synapses of guinea pig hippocampus. Soc Neurosci Abstr 19:1518.

Wu LG, Saggau P (1994) Presynaptic calcium is increased during normal synaptic transmission and paired-pulse facilitation, but not in long-term potentiation in area $\mathrm{CA} 1$ of hippocampus. J Neurosci 14:645-654.

Yawo H, Chuhma N (1993) Preferential inhibition of $\omega$-conotoxinsensitive presynaptic $\mathrm{Ca}^{2+}$ channels by adenosine autoreceptors. $\mathrm{Na}-$ ture 365:256-258.

Zucker RS (1993) Calcium and transmitter release at nerve terminals. Biochem Soc Trans 21:395-401.

Zucker RS, Delaney KR, Mulkey R, Tank DW (1991) Presynaptic calcium in transmitter release and posttetanic potentiation. Ann NY Acad Sci 635:191-207. 